\title{
Associations between milk protein concentration, milk yield, and reproductive performance in dairy cows
}

\author{
J. M. Morton, ${ }^{\star 1}$ M. J. Auldist, $†$ M. L. Douglas, $\nmid$ and K. L. Macmillan $\ddagger$ \\ *Jemora Pty Ltd., Geelong, Victoria 3220, Australia \\ †Department of Economic Development, Jobs, Transport and Resources, Ellinbank Centre, Victoria 3821, Australia \\ †Department of Veterinary and Agricultural Sciences, The University of Melbourne, 250 Princes Highway, Werribee, Victoria 3030, Australia
}

\section{ABSTRACT}

Milk protein concentration in dairy cows has been positively associated with a range of measures of reproductive performance. It was possible that these associations were due to confounding by milk volume. A retrospective single cohort study was conducted using data collected from 74 dairy herds with seasonal or split calving patterns. Associations between milk protein concentration and reproductive performance in Holstein dairy cows were assessed using random effects logistic regression. The key finding from this study was that the associations between milk protein concentration in early lactation and reproductive performance were not due to confounding by milk yield. Associations between milk protein concentration and reproductive performance were weaker at higher early lactation milk yields, but positive associations were evident at all milk volumes assessed. The second major finding was that increases in milk yield were associated with improved proportions of cows pregnant by wk 6 and 21 at low to moderate milk protein concentrations but with decreases in these reproductive measures at high milk protein concentrations. Thus, no simple relationship is present between milk yield and reproductive performance; effects of milk yield depend on milk protein concentration. These results indicate that mechanisms causing the associations between milk protein concentration and reproductive performance may be linked to milk yield but these mechanisms operate over a wide range of milk yields $(<2,000$ to $\geq 5,000 \mathrm{~kg}$ in the first $120 \mathrm{~d}$ of lactation). Further research is required to identify the causes of these associations.

Key words: milk protein concentration, milk yield, reproductive performance, dairy cow

Received April 5, 2016.

Accepted August 3, 2016.

${ }^{1}$ Corresponding author: john.morton@optusnet.com.au

\section{INTRODUCTION}

Milk protein concentration has been positively associated with reproductive performance in dairy cows in both seasonally calving (Fahey et al., 2003; Harris and Pryce, 2004; Patton et al., 2007) and year-round calving herds (Lampo et al., 1963; Kaufmann, 1976; Miettinen and Setala, 1993). Higher milk protein concentration has been associated with shorter calving to first estrus intervals among primipara (McGowan et al., 1996), shorter calving to first service intervals (Miettinen and Setala, 1993), higher submission (Buckley et al., 2003) and conception rates (Leaver, 1983; Pinto et al., 2000), reduced risk of requiring multiple inseminations (Moss et al., 2002), and increased pregnancy rates by wk 6 of the breeding period (Buckley et al., 2003) and at the end of the breeding program (Kennedy et al., 2003). Among cows treated for anestrus, milk protein concentration is also positively associated with pregnancy rates (McDougall, 2003). Increased conception rates among cows with higher milk protein concentration appear to be due to increased fertilization rates, decreased early embryonic mortality, or both (Pinto et al., 2000), but not to reduced late embryonic mortality (Silke et al., 2002).

It is possible that this association between milk protein concentration and reproductive performance is due to effects of milk yield, as milk yield is negatively associated with both milk protein concentration and reproductive performance. The genetic and phenotypic correlations between milk protein concentration and milk yield in New Zealand cows were estimated to be -0.61 and -0.44 , with heritabilities of 0.52 and 0.35 , respectively (Harris and Pryce, 2004). Shanks et al. (1982) reported correlation coefficients of 0.13 to 0.19 for associations between peak milk yield and calving interval. Hamudikuwanda et al. (1987) observed increases in calving interval of $6 \mathrm{~d}$ for every 1,000 $\mathrm{L}$ increase in 60-d cumulative milk yield, and Eicker et al. (1996) found that cows producing more than $2,541 \mathrm{~L}$ in the first $60 \mathrm{~d}$ of lactation had a slightly lower chance of conception. Laben et al. (1982) detected increases in 
calving interval of $6 \mathrm{~d}$ per 1,000 L increase in 180-d cumulative milk yield and Kinsel et al. (1998) reported increases in days open of $2 \mathrm{~d}$ for every extra $10 \mathrm{~L}$ of peak daily milk yield. Mean days open was $17 \mathrm{~d}$ longer among cows partitioning over $125 \mathrm{MJ} / \mathrm{d}$ to milk in early lactation, relative to cows partitioning less than 65 MJ (Klaas et al., 2004).

Thus, the primary objectives of the current study were (1) to assess the strengths of associations between milk protein concentration in early lactation and various measures of reproductive performance in Holstein cows after adjusting for milk yield, and (2) to assess interactions between milk protein concentrations and milk yield. A secondary objective was to assess effects of milk yield on reproductive performance.

\section{MATERIALS AND METHODS}

\section{Study Overview}

A retrospective, single cohort study was conducted using data collected from 74 Australian dairy herds. Associations between early lactation milk protein concentration and reproductive performance, and interactions with early lactation milk yield, were assessed in Holstein dairy cows using random effects logistic regression. Full details of the study have been reported elsewhere (Morton et al., 2016). Briefly, in 2010, veterinarians from 4 practices in Victoria and Tasmania, Australia, selected commercial client herds with accessible electronically stored data that met the study's herd selection criteria. The primary criteria were adequate pregnancy testing and complete and accurate calving, AI, pregnancy test, and culling data in an electronic database. For the 2009 calving period (or, for split-calving herds, the largest calving group in 2009), whole-herd rectal pregnancy testing within $17 \mathrm{wk}$ after breeding period start date using rectal ultrasound or manual examination must have been conducted, with cows not diagnosed pregnant retested after the end of the breeding period. In addition, all herd-years with sufficient early pregnancy test data in the Australian Dairy Herd Improvement Scheme (ADHIS, 2015) national database were identified and enrolled. In selecting herds from the ADHIS data, herds from throughout Australia were eligible. However, the only herds that met the selection criteria were from Victoria. All relevant data in the respective databases for the selected herds were obtained and used where study criteria were met. Breeding periods from 1996 to 2009 were used in analyses.

Every enrolled herd had either a seasonally concentrated or a split calving pattern (i.e., 1 to 3 distinct calving periods within each year). For each breeding period, most initially used AI exclusively for some weeks before running bulls with the lactating herd. Start of breeding period dates were determined within each herd based on daily numbers of services (i.e., AI and natural services). As dates that bulls were removed from the lactating herds and bull services were generally not recorded, end dates for each breeding period were defined based on conception dates. Conception dates were assigned only for cows with positive pregnancy diagnoses. These were identified based on estimated stages of pregnancy from positive rectal pregnancy diagnoses in combination with AI and any recorded bull services.

All lactations by Holstein cows commencing between $120 \mathrm{~d}$ before and $30 \mathrm{~d}$ after their nearest breeding period start date were selected and allocated the nearest breeding period start date. Where the herd had 2 breeding periods commencing $120 \mathrm{~d}$ or less apart, calvings between these start dates were allocated the second breeding period start date. Other lactations were excluded from analyses. Breeding periods where arbitrary calving dates had been recorded (e.g., all calvings recorded as occurring on the first day of the calendar month) were also excluded from analyses, as were lactations with service or conception dates (or both) before breeding period start date. Breeding periods were considered to have adequate data for analyses only if they had been allocated more than 50 lactations, and for more than $80 \%$ of the ensuing lactations, the cow had at least one pregnancy diagnosis.

Four lactation-level binary reproductive performance measures were used as outcome (i.e., dependent) variables:

- submission (i.e., inseminated or served) by wk 3 of the breeding period,

- conception to first service (for lactations where the first service was by AI)

- pregnancy by wk 6 of the breeding period, and

- pregnancy by the end of the breeding period (considering only pregnancies up to the end of wk 21 of the breeding period).

For each reproductive measure, all selected lactations were included if the cow's status for that measure could be ascertained. For example, submitted by wk 3 of the breeding period could be ascertained only for cows not culled by that time, and pregnancy by wh 6 of the breeding period could be ascertained only for cows diagnosed pregnant or whose final pregnancy test was at least $70 \mathrm{~d}$ after the start of the breeding period.

\section{Milk Protein Concentrations and Milk Yields}

Milk protein concentrations and milk yields had been estimated by commercial milk recording services. Milk 
recording was generally conducted in one 24 -h period each 4 to $8 \mathrm{wk}$. Milk protein concentrations were calculated for the first $120 \mathrm{~d}$ of each lactation using $24-\mathrm{h}$ milk recording data. For each 24 -h test day, 24 -h protein yields were calculated as milk protein concentration multiplied by milk yield. All test days until 120 $\mathrm{d}$ after calving and the next 24-h estimate were used. Milk protein concentration was calculated as 120-d protein yield divided by $120-\mathrm{d}$ milk yield. These were calculated, respectively, as areas under the lactation curves of 24-h protein yield and milk yield by time from calving. Lactation curves were defined assuming the same 24-h yields and yields from calving to first milk recording and linear interpolation between milk recordings. Lactations where the calculated 120-d milk protein concentration was $8 \%$ or higher were excluded from analyses.

\section{Statistical Methods}

Analyses were completed using Stata (version 13, StataCorp, College Station, TX). Only Holstein cows were used. Numbers of lactations and percentages of these experiencing each reproductive outcome were calculated for various combinations of milk protein concentration and milk yield categories.

Linearity in the logit between milk protein concentration and each reproductive outcome was assessed by visual assessment of lowess (locally weighted regression) plots after lowess regression of each reproductive outcome on milk protein concentration; smoothed probabilities were transformed into logits before plotting. Stata's lowess command was used. Associations between milk protein concentration and reproductive performance measures were approximately linear in the logit over the range of the most common milk protein concentrations of 2.75 to $3.75 \%$, so milk protein concentration was fitted as a continuous variable in all models. As 2 previous Australian studies have detected curvilinear associations between milk yield and reproductive performance (Morton, 2004, 2011), milk yield was fitted as a categorical variable (with 5 categories) in all models.

Associations between milk protein concentrations and each reproductive outcome were assessed with milk yield fitted as a covariate using random effects logistic regression, with herd fitted as a random effect using the xtlogit command in Stata. Cow age at calving, source of data, and year of breeding period start (1996 to 2009) were also fitted as categorical data covariates, and intervals from calving to breeding period start (linear and quadratic terms) were also fitted as continuous data covariates. Source of data had 7 categories: each of the 4 veterinary practices and, for herds sourced from ADHIS, the herd's region (Gippsland, southwest Victoria or northern Victoria). For conceived to first service, linear and quadratic terms for calving to breeding period start were replaced with linear and quadratic terms for calving to service interval. Interactions between milk protein concentration and milk yield value were assessed with the same covariates. For each reproductive outcome, likelihood ratio test $P$ values were used to assess the interaction term. Odds ratios for a 1 percentage point increase in milk protein concentration were estimated for each of five 120-d milk yield categories $(<2,000 \mathrm{~kg}, 2,000$ to $<3,000,3,000$ to $<4,000,4,000$ to $<5,000$, and $\geq 5,000 \mathrm{~kg}$ ). Probabilities of each reproductive outcome were predicted from these models for various milk protein concentrations using Stata's margins command. The correlation between milk protein concentration and milk yield was assessed using Pearson correlation coefficient. Mean milk protein concentrations were compared between milk yield categories using mixed effects linear regression fitted using Stata's mixed command, with cow age at calving, source of data, and year of breeding period start included as covariates and with herd fitted as a random effect. Both analyses were performed using the same lactations as used for analyses of the association between milk protein concentration and pregnancy by wk 6 .

\section{Numbers of Herds and Lactations}

Fifty-eight herds were enrolled from veterinary practices and 20 herds from the ADHIS national database. Overall, 74 unique herds were enrolled as 4 herds were represented in both sources. One herd was subsequently excluded as substantial numbers of cows and calvings had not been entered into the database.

These 73 herds provided data for 126,277 cows; these cows had 359,892 calvings (and hence lactations) recorded. Exclusions sequentially were as follows:

- lactations not commencing on or between $120 \mathrm{~d}$ before and $30 \mathrm{~d}$ after each breeding period start date $(\mathrm{n}=86,824$, leaving 273,068),

- duplicated lactations ( $\mathrm{n}=4,246$, leaving 268,822),

- breeding period did not have adequate data for analyses ( $\mathrm{n}=84,371$, leaving 184,451),

- lactations allocated to 4 breeding periods where arbitrary calving dates had been recorded $(\mathrm{n}=$ 1,362 , leaving 183,089),

- cow not recorded as Holstein ( $\mathrm{n}=94,594$, leaving $88,495)$,

- date of birth not recorded for cow ( $\mathrm{n}=1,343$, leaving 87,152 ), 
Table 1. Percentages of lactations where the cow was submitted by wk 3 , by milk protein concentration (milk protein $\%$ ) and milk yield in the first $120 \mathrm{~d}$ of lactation

\begin{tabular}{|c|c|c|c|c|c|c|}
\hline \multirow[b]{2}{*}{ Milk protein (\%) } & \multicolumn{6}{|c|}{ 120-d milk yield (kg) } \\
\hline & $<2,000$ & 2,000 to $<3,000$ & 3,000 to $<4,000$ & 4,000 to $<5,000$ & $\geq 5,000$ & Pooled \\
\hline 2.75 to $<3.00$ & 51.6 & 57.2 & 61.0 & 61.0 & 62.2 & 60.0 \\
\hline 3.00 to $<3.25$ & 56.8 & 63.0 & 67.3 & 66.1 & 67.5 & 65.8 \\
\hline 3.25 to $<3.50$ & 65.8 & 69.0 & 71.1 & 70.7 & 72.0 & 70.2 \\
\hline 3.50 to $<3.75$ & 65.2 & 74.6 & 73.1 & 73.4 & $78.3^{1}$ & 73.4 \\
\hline
\end{tabular}

${ }^{1}$ Denominator (number of lactations) was $<250$; numbers varied from 12 to 142 ; denominators for other nonpooled cells varied from 250 to 24,913 ; total $\mathrm{n}=62,556$

- reproductive outcome could not be determined (for pregnancy by wk $6, \mathrm{n}=2,731$, leaving 84,421 ), and

- milk protein concentration not available or $\geq 8 \%$ ( $\mathrm{n}=22,067$, leaving 62,354).

Thus, 62,354 lactations were used for analyses of the association between milk protein concentration and pregnancy by wk 6 . These lactations were from 24,610 cows in 63 herds. Numbers varied for other reproductive outcomes.

\section{RESULTS}

\section{Correlations Between Milk Protein Concentration and Milk Yield}

Milk protein concentration and milk yield were negatively correlated (Pearson correlation coefficient -0.187 ; 95\% CI not adjusted for clustering of lactations within herds: -0.194 to -0.179$)$. Relative to cows with milk yields of $<2,000 \mathrm{~kg}$, mean milk protein concentrations for milk yields of 2,000 to $<3,000,3,000$ to $<4,000$, 4,000 to $<5,000$, and $\geq 5,000 \mathrm{~kg}$ were, respectively, $0.05 \%$ lower (95\% CI 0.04 to $0.07 \%$ ), $0.10 \%$ lower $(95 \%$
CI 0.09 to $0.11 \%$ ), $0.17 \%$ lower (95\% CI 0.16 to $0.18 \%$ ), and $0.26 \%$ lower (95\% CI 0.24 to $0.27 \%$ ).

\section{Associations Between Milk Protein Concentration and Reproductive Outcomes}

Percentages of lactations where the cow was submitted by wk 3 by milk protein concentration and milk yield are shown in Table 1 , and effects of a 1 percentage point increase in milk protein concentration at various 120-d milk yield categories on odds of the cow being submitted by wk 3 are shown in Table 2 and Figure 1 . Corresponding results for conceived to first service are shown in Tables 3 and 4, and Figure 2, for pregnancy by wk 6 in Tables 5 and 6 , and Figure 3, and pregnancy by wk 21 in Tables 7 and 8, and Figure 4. Results were similar for submission by wk 3 , pregnancy by wk 6 , and pregnancy by wk 21. Within each milk yield category, crude percentages generally improved markedly with increased milk protein concentration (Tables 1,5 , and 7 ). After adjustment for milk yield and other covariates, odds ratios for the effects of a 1 percentage point increase in milk protein concentration generally indicated strong associations between milk protein con-

Table 2. Effects of a one percentage point increase in milk protein concentration at various 120 -d milk yield categories on odds of the cow being submitted by wk 3

\begin{tabular}{|c|c|c|c|}
\hline Milk yield (kg) & $\begin{array}{l}\text { Adjusted } \\
\text { odds ratio }^{1}\end{array}$ & $95 \%$ CI & $P$-value \\
\hline All milk yields pooled & $2.07^{2}$ & 1.90 to 2.27 & $<0.001$ \\
\hline$<2,000$ & 2.28 & 1.58 to 3.29 & $<0.001$ \\
\hline 2,000 to $<3,000$ & 2.47 & 2.13 to 2.86 & $<0.001$ \\
\hline 3,000 to $<4,000$ & 1.89 & 1.66 to 2.16 & $<0.001$ \\
\hline 4,000 to $<5,000$ & 1.84 & 1.50 to 2.26 & $<0.001$ \\
\hline$\geq 5,000$ & 1.77 & 1.07 to 2.95 & 0.027 \\
\hline
\end{tabular}

${ }^{1}$ Adjusted for cow age at calving, source of data, year of breeding period start date, and interval from calving to breeding period start date (linear and quadratic terms); herd was fitted as a random effect.

${ }^{2}$ Also adjusted for milk yield. 


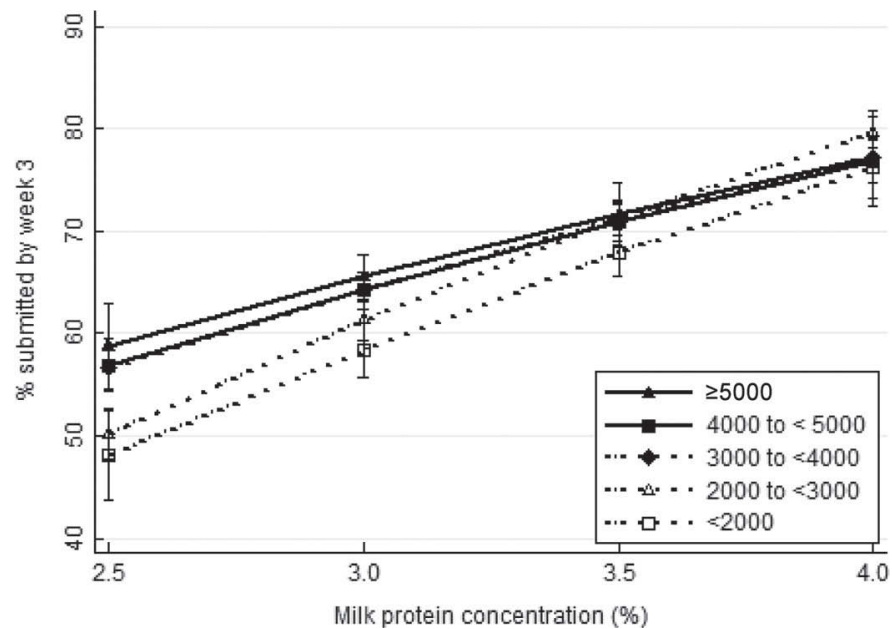

Figure 1. Adjusted proportions (expressed as percentages) of lactations where the cow was submitted by wk 3 by milk protein concentration and milk yield in the first $120 \mathrm{~d}$ of lactation $(\mathrm{kg})$. Milk yield categories are shown in the legend. Error bars indicate SEM. Proportions are as predicted at mean values for cow age at calving, source of data, year of breeding period start, and interval from calving to breeding period start (linear and quadratic terms); herd was fitted as a random effect and predictions are for a random intercept value of 0

centration and the reproductive measures assessed (i.e., odds ratios were generally well above 1 ; Tables 2,6 , and 8). Collectively, these results indicate that variation in milk yield does not account for the association between milk protein concentration in early lactation and these reproductive outcomes.

Effects of milk protein concentration varied markedly with milk yield. The $P$-values for interactions between milk protein concentration and milk yield were 0.048 , $<0.001$, and $<0.001$, respectively, for submission by wk 3 , pregnancy by wk 6 , and pregnancy by wk 21 . Within all milk yield categories other than $\geq 5,000 \mathrm{~kg}$, adjusted probabilities increased approximately linearly with increases in milk protein concentration. However, slopes (Figures 1, 3, and 4) and odds ratios (Tables 2, 6, and
8) varied depending on milk yield. Associations were strongest at lower milk yields and weaker at high milk yields. Odds ratio estimates were imprecise at milk yields $\geq 5,000 \mathrm{~kg}$, but point estimates were consistent with weaker effects than at lower milk yields (Tables 2 , 4 , and 6 ).

Results differed somewhat for conception to first service. Crude percentages generally improved markedly with increased milk protein concentration (Table 3). After adjustment for milk yield and other covariates, the odds ratio for the effects of a 1 percentage point increase in milk protein concentration was 1.47 (Table 4). These results indicate that milk yield does not account for the association between milk protein concentration and conception to first service and that the association is weaker than for the other 3 measures of reproductive performance. Also in contrast to the other 3 measures, no large interaction was present between milk protein concentration and milk yield in their effects on conception to first service. The $P$-value for interaction was 0.174 , with odds ratios (Table 8) and slopes (Figure 2) more similar at all milk yields. For conception to first service, modest interactions would probably not have been detected by our study. Within milk yields of $<2,000 \mathrm{~kg}$, a 1 percentage point increase in milk protein concentration equated to an increase in conception rate from, for example, 40 to $53 \%$. Relative to this effect, the odds ratios for the interaction term for milk yields of 2,000 to $<3,000 \mathrm{~kg}$ was 0.98 (95\% CI 0.7 to 1.4 ). Thus, for milk yields of 2,000 to $<3,000 \mathrm{~kg}$, a 1 percentage point increase in milk protein concentration equated to an increase in conception rate from, for example, 40 to $52 \%(95 \%$ CI 43 to $62 \%$ ) or $1 \%$ less than within milk yields of $<2,000 \mathrm{~kg}$ ( $95 \%$ CI $10 \%$ less to $9 \%$ more). In other words, assuming no prior information about the magnitude of this interaction and at a base conception rate of $40 \%$, the effect of milk protein concentration within milk yields of 2,000 to $<3,000 \mathrm{~kg}$ could differ by as much as 9 to 10 percentage points from the effect

Table 3. Percentages of lactations where the cow conceived to first service, by milk protein concentration (milk protein \%) and milk yield in the first $120 \mathrm{~d}$ of lactation

120-d milk yield $(\mathrm{kg})$

\begin{tabular}{|c|c|c|c|c|c|c|}
\hline \multirow[b]{2}{*}{ Milk protein $(\%)$} & \\
\hline & $<2,000$ & 2,000 to $<3,000$ & 3,000 to $<4,000$ & 4,000 to $<5,000$ & $\geq 5,000$ & Pooled \\
\hline 2.75 to $<3.00$ & $36.8^{1}$ & 38.7 & 35.5 & 32.9 & 28.6 & 35.0 \\
\hline 3.00 to $<3.25$ & 38.7 & 40.0 & 37.5 & 34.5 & 31.2 & 37.1 \\
\hline 3.50 to $<3.75$ & $46.0^{1}$ & 45.4 & 41.3 & 37.6 & $36.4^{1}$ & 42.6 \\
\hline$>3.75$ & $43.9^{1}$ & 47.1 & 45.2 & $36.6^{1}$ & $18.2^{1}$ & 45.0 \\
\hline Pooled & 41.5 & 41.3 & 38.0 & 34.7 & 31.2 & 38.0 \\
\hline
\end{tabular}

${ }^{1}$ Denominator (number of lactations) was $<250$; numbers varied from 11 to 211 ; denominators for other nonpooled cells varied from 301 to 20,$963 ;$ total $\mathrm{n}=52,984$. 


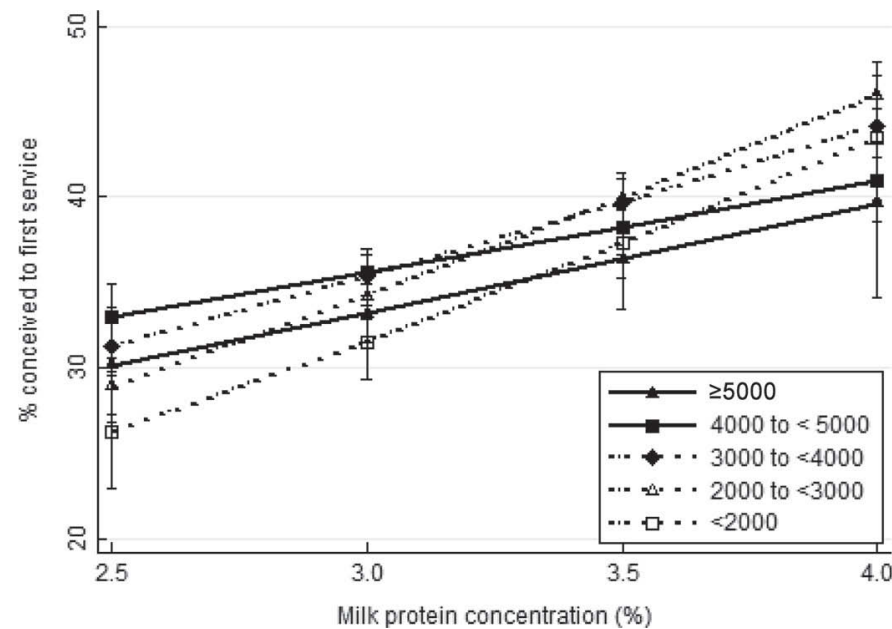

Figure 2. Adjusted proportions (expressed as percentages) of lactations where the cow conceived to first service by milk protein concentration and milk yield in the first $120 \mathrm{~d}$ of lactation $(\mathrm{kg})$. Milk yield categories are shown in the legend. Error bars indicate SEM. Proportions are as predicted at mean values for cow age at calving, source of data, year of breeding period start, and interval from calving to first service (linear and quadratic terms); herd was fitted as a random effect and predictions are for a random intercept value of 0 .

within milk yields of $<2,000 \mathrm{~kg}$. Odds ratios for interaction terms for milk yields of 3,000 to $<4,000 \mathrm{~kg}, 4,000$ to $<5,000 \mathrm{~kg}$, and $\geq 5,000$ were, respectively, $0.9(95 \%$ CI 0.6 to 1.3$), 0.8$ (95\% CI 0.5 to 1.1$)$, and $0.8(95 \%$ CI 0.4 to 1.4$)$.

\section{Associations Between Milk Yield and Reproductive Outcomes}

Due to the interactions between milk protein concentration and milk yield, effects of early lactation milk yield varied with milk protein concentration. At low to moderate milk protein concentrations, submission by wk 3 , pregnancy by wk 6 , and pregnancy by wk 21 increased in association with increases in milk yield (Tables 1, 5, and 7; Figures 1, 3, and 4). For pregnancy by wk 6 , and pregnancy by wk 21 , the association was reversed at high milk protein concentrations, where reproductive performance decreased in association with increases in milk yield. Based on adjusted proportions of lactations where the cow conceived to first service (Figure 2), similar patterns were evident for conception to first service. However, those point estimates were imprecise and the $P$-value for interaction was 0.174 . After removing the interaction terms, relative to milk yields $<2,000 \mathrm{~kg}$, odds ratio for conception to first service were 1.11 (95\% CI 0.99 to $1.26 ; P=0.075), 1.13$ (95\% CI 1.00 to $1.28 ; P=0.044), 1.12$ (95\% CI 0.98 to $1.28 ; P=0.095)$, and 1.02 (95\% CI 0.87 to $1.21 ; P=$ 0.784 ) for 2,000 to $<3,000 \mathrm{~kg}, 3,000$ to $<4,000 \mathrm{~kg}, 4,000$

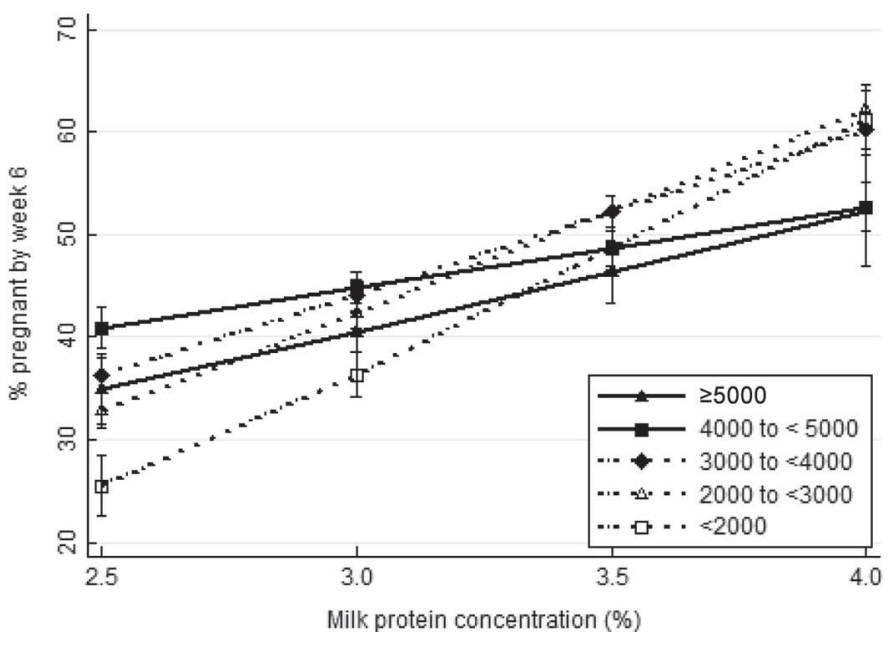

Figure 3. Adjusted proportions (expressed as percentages) of lactations where the cow became pregnant by wk 6 by milk protein concentration and milk yield in the first $120 \mathrm{~d}$ of lactation $(\mathrm{kg})$. Milk yield categories are shown in the legend. Error bars indicate SEM. Proportions are as predicted at mean values for cow age at calving, source of data, year of breeding period start, and interval from calving to breeding period start (linear and quadratic terms); herd was fitted as a random effect and predictions are for a random intercept value of 0 .

to $<5,000 \mathrm{~kg}$, and $\geq 5,000 \mathrm{~kg}$, respectively. Relative to 3,000 to $<4,000 \mathrm{~kg}$, the odds ratio for conception to first service for $\geq 5,000 \mathrm{~kg}$ was 0.90 (95\% CI 0.81 to 1.01; $P=0.068)$. These odds ratios were adjusted for milk protein concentrations and indicate that the probability of conception to first service increases with milk yield up to intermediate milk yields. For submission by wk 3, no large effects of milk yield were evident at high milk protein concentrations (Table 1 and Figure 1).

\section{DISCUSSION}

The most important finding from this study is that, even though early lactation milk protein concentration and milk yield are negatively associated, associations between milk protein concentration in early lactation and reproductive performance in Holstein cows were not due to confounding by milk yield. Although associations between milk protein concentration and reproductive performance were weaker at higher early lactation milk yields, positive associations were evident at all milk yields assessed. These findings indicate that mechanisms causing the associations between milk protein concentration and reproductive performance may be linked to milk yield but that these mechanisms operate over a wide range of milk yields $(<2,000$ to $\geq 5,000 \mathrm{~kg}$ in the first $120 \mathrm{~d}$ of lactation). The second major finding was that, in populations such as the study population, increases in milk yield are associated 
Table 4. Effects of a one percentage point increase in milk protein concentration at various 120-d milk yield categories on odds of the cow conceiving to first service

\begin{tabular}{lccr}
\hline Milk yield $(\mathrm{kg})$ & $\begin{array}{c}\text { Adjusted } \\
\text { odds ratio }^{1}\end{array}$ & $95 \%$ CI & $P$-value \\
\hline All milk yields pooled & $1.47^{2}$ & 1.36 to 1.60 & $<0.001$ \\
$<2,000$ & 1.67 & 1.16 to 2.41 & 0.006 \\
2,000 to $<3,000$ & 1.64 & 1.43 to 1.87 & $<0.001$ \\
3,000 to $<4,000$ & 1.45 & 1.29 to 1.63 & $<0.001$ \\
4,000 to $<5,000$ & 1.26 & 1.05 to 1.50 & 0.013 \\
$\geq 5,000$ & 1.32 & 0.83 to 2.10 & 0.239 \\
\hline
\end{tabular}

${ }^{1}$ Adjusted for cow age at calving, source of data, year of breeding period start date, and calving to first service interval (linear and quadratic terms); herd was fitted as a random effect.

${ }^{2}$ Also adjusted for milk yield.

Table 5. Percentages of lactations where the cow became pregnant by wk 6 , by milk protein concentration (milk protein \%) and milk yield in the first $120 \mathrm{~d}$ of lactation

\begin{tabular}{|c|c|c|c|c|c|c|}
\hline Milk protein (\%) & \multicolumn{6}{|c|}{ 120-d milk yield (kg) } \\
\hline$<2.75$ & $32.7^{1}$ & 37.5 & 35.4 & 35.6 & $30.1^{1}$ & 35.6 \\
\hline 2.75 to $<3.00$ & $34.9^{1}$ & 43.9 & 42.4 & 40.5 & 36.4 & 41.7 \\
\hline 3.00 to $<3.25$ & 42.4 & 49.5 & 48.8 & 44.5 & 40.4 & 47.5 \\
\hline 3.25 to $<3.50$ & 57.0 & 55.8 & 52.7 & 48.8 & 46.0 & 52.9 \\
\hline 3.50 to $<3.75$ & 54.8 & 58.8 & 57.1 & 48.9 & $50.0^{1}$ & 56.6 \\
\hline
\end{tabular}

${ }^{1}$ Denominator (number of lactations) was $<250$; numbers varied from 12 to 249 ; denominators for other nonpooled cells varied from 263 to 24,$835 ;$ total $n=62,354$

Table 6. Effects of a one percentage point increase in milk protein concentration at various 120-d milk yield categories on odds of the cow becoming pregnant by wk 6

\begin{tabular}{lccc}
\hline Milk yield $(\mathrm{kg})$ & $\begin{array}{c}\text { Adjusted } \\
\text { odds ratio }^{1}\end{array}$ & $95 \%$ CI & $P$-value \\
\hline All milk yields pooled & $1.93^{2}$ & 1.78 to 2.08 & $<0.001$ \\
$<2,000$ & 2.77 & 1.98 to 3.86 & $<0.001$ \\
2,000 to $<3,000$ & 2.24 & 1.97 to 2.55 & $<0.001$ \\
3,000 to $<4,000$ & 1.91 & 1.71 to 2.14 & $<0.001$ \\
4,000 to $<5,000$ & 1.37 & 1.16 to 1.63 & $<0.001$ \\
$\geq 5,000$ & 1.61 & 1.04 to 2.50 & 0.032 \\
\hline
\end{tabular}

${ }^{1}$ Adjusted for cow age at calving, source of data, year of breeding period start, and interval from calving to breeding period start (linear and quadratic terms); herd was fitted as a random effect.

${ }^{2}$ Also adjusted for milk yield.

Table 7. Percentages of lactations where the cow became pregnant by wk 21, by milk protein concentration (milk protein \%) and milk yield in the first $120 \mathrm{~d}$ of lactation

\begin{tabular}{|c|c|c|c|c|c|c|}
\hline \multirow[b]{2}{*}{ Milk protein (\%) } & \multicolumn{6}{|c|}{ 120-d milk yield (kg) } \\
\hline & $<2,000$ & 2,000 to $<3,000$ & 3,000 to $<4,000$ & 4,000 to $<5,000$ & $\geq 5,000$ & Pooled \\
\hline$<2.75$ & $66.7^{1}$ & 67.6 & 68.1 & 63.5 & $66.7^{1}$ & 66.6 \\
\hline 2.75 to $<3.00$ & $71.6^{1}$ & 76.6 & 76.1 & 72.7 & 66.2 & 74.6 \\
\hline 3.00 to $<3.25$ & 76.6 & 81.1 & 80.8 & 76.5 & 72.4 & 79.5 \\
\hline 3.25 to $<3.50$ & 86.2 & 85.0 & 83.2 & 79.1 & 76.5 & 83.0 \\
\hline 3.50 to $<3.75$ & 81.9 & 87.6 & 84.9 & 82.0 & $86.0^{1}$ & 85.5 \\
\hline
\end{tabular}

${ }^{1}$ Denominator (number of lactations) was $<250$; numbers varied from 12 to 243 ; denominators for other nonpooled cells varied from 259 to 24,$111 ;$ total $n=60,814$. 


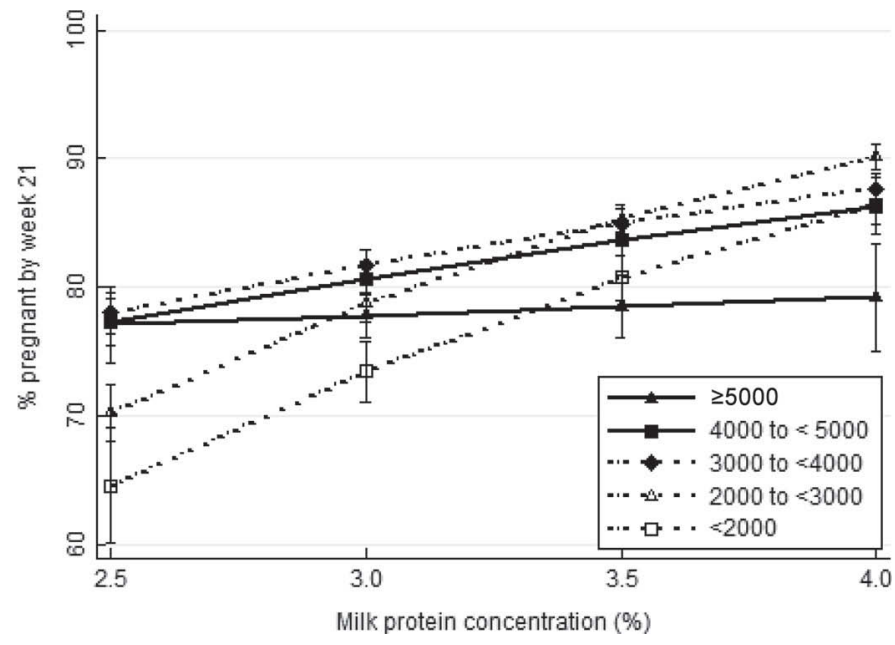

Figure 4. Adjusted proportions (expressed as percentages) of lactations where the cow became pregnant by wk 21 by milk protein concentration and milk yield in the first $120 \mathrm{~d}$ of lactation $(\mathrm{kg})$. Milk yield categories are shown in the legend. Error bars indicate SEM. Proportions are as predicted at mean values for cow age at calving, source of data, year of breeding period start, and interval from calving to breeding period start (linear and quadratic terms); herd was fitted as a random effect and predictions are for a random intercept value of 0 .

with improved proportions of cows pregnant by wk 6 and 21 at low to moderate milk protein concentrations, but with decreases in these reproductive performance measures at high milk protein concentrations. Thus, there is no simple relationship between milk yield and these reproductive performance measures; effects of milk yield depend on milk protein concentration.

Odds ratios for effects of milk protein concentration were weaker with increasing milk yield. However, only 21 and $3 \%$ of the study cows produced $\geq 4,000$ to $<5,000$ and $\geq 5,000 \mathrm{~L}$ by $120 \mathrm{~d}$ of lactation, respectively. For most cows in Australian herds, milk yields are currently in the range where the associations between milk protein concentration and reproductive performance are strongest $(<4,000 \mathrm{~L}$ in the first 120 $\mathrm{d}$ of lactation). Based on our results, weaker associations would be expected with higher-producing cows and herds. However, even in these cows and herds, our results indicate that the causal mechanisms are still having important effects. Our results primarily reflect within- (rather than between-) herd comparisons. In Australia, concentrate supplements are typically fed at differing rates per cow throughout the year, but on any given day, the same amount is fed to each cow, regardless of milk yield. The higher yielding cows are those that eat more pasture and forage, lose more body tissue in early lactation, or both. High yielding cows have greater daily energy requirements for milk production to supply lactose than lower yielding cows with the same milk composition, but reasons for milk yield moderating the causal mechanisms for the milk protein concentration-reproductive performance association are not known. Milk yield may have been considered the obvious mechanism explaining the association due to its link with increased body tissue mobilization in early lactation. However, this research and other studies of the same association (Fahey et al., 2008, 2016; Morton et al., 2016) indicate other underlying mechanisms. Further research to identify these underlying mechanisms is important.

For the first $120 \mathrm{~d}$ of lactation, most study cows (96\%) had milk protein concentrations between 2.75 and $3.75 \%$, and across all milk yields pooled, a $1 \%$ increase in milk protein concentration was associated with increases in odds of 2.07 for submission by the end of wk 3 of the breeding period, 1.47 for conception to first service, 1.93 for pregnancy by wk 6 , and 1.80 for pregnancy by wk $21(P<0.001$ for all; Tables 2,4 , 6 , and 8). Cows with the lowest milk protein concentrations $(<2.75 \%)$ had below average crude pregnancy rate at wk 6 (i.e., a lower proportion became pregnant by wk 6 ) irrespective of milk yield category (from 9 to $16 \%$ below the average for all milk protein concentrations pooled; Table 5) mainly because of lower crude submission rates by wk 3 (from 13 to $16 \%$ below the

Table 8. Effects of a one percentage point increase in milk protein concentration at various 120-d milk yield categories on odds of the cow becoming pregnant by wk 21

\begin{tabular}{lccc}
\hline Milk yield $(\mathrm{kg})$ & $\begin{array}{c}\text { Adjusted } \\
\text { odds ratio }^{1}\end{array}$ & $95 \%$ CI & $P$-value \\
\hline All milk yields pooled & $1.80^{2}$ & 1.64 to 1.99 & $<0.001$ \\
$<2,000$ & 2.30 & 1.51 to 3.50 & $<0.001$ \\
2,000 to $<3,000$ & 2.47 & 2.09 to 2.93 & $<0.001$ \\
3,000 to $<4,000$ & 1.59 & 1.38 to 1.84 & $<0.001$ \\
4,000 to $<5,000$ & 1.51 & 1.23 to 1.85 & $<0.001$ \\
$\geq 5,000$ & 1.09 & 0.67 to 1.77 & 0.732 \\
\hline
\end{tabular}

${ }^{1}$ Adjusted for cow age at calving, source of data, year of breeding period start, and interval from calving to breeding period start (linear and quadratic terms); herd was fitted as a random effect.

${ }^{2}$ Also adjusted for milk yield. 
average for all milk protein concentrations pooled; Table 1) rather than lower crude conception rates to first insemination (from $5 \%$ below the average to $2 \%$ higher; Table 3). These results show that mechanisms causing the associations between milk protein concentration and reproductive performance have larger effects on probability of submission by wk 3 than on probability of conception to first service.

Measuring reproductive performance in seasonally calving herds by calculating the percentage of cows retrospectively confirmed pregnant by the sixth week of the breeding period is a standard practice in the Australian and New Zealand dairy industries ( $\mathrm{Xu}$ and Burton, 2003; Morton, 2004). This measure of reproductive performance in seasonally calving herds was originally recommended by Grosshans et al. (1997). They reported that 6 -wk pregnancy rates were 73 and $74 \%$ in Friesian cows in their first or second lactations in New Zealand herds. These results were achieved with submission rates at 3 wk of $80 \%$ and a probability of conception to first insemination of $58 \%$. A subsequent study in New Zealand reported an average 6-wk pregnancy rate in Friesian cows of $70 \%$ ( $\mathrm{Xu}$ and Burton, 2003). In the current study, the crude 3 -wk submission rate, first insemination conception rate, and 6 -wk pregnancy rate were 67,38 , and $49 \%$, respectively (Tables 1,3 , and 5 , respectively). The declines in the 6 -wk pregnancy rate in New Zealand herds between the 1997 study and the 2003 study have been attributed to increased use of Holstein sires (Harris and Kolver, 2001). However, the decline in 6-wk pregnancy rate from 63 to $49 \%$ that has occurred in seasonally calving Australian herds (Morton, 2004, 2011) is substantially greater.

Many researchers have described negative associations between milk yield and reproductive performance, as cited by Grosshans et al. (1997) and Madouasse et al. (2010). However, few studies have assessed relationships between milk yield and reproductive performance using data from cows in pasture-based, seasonal, and split calving herds, and no previous studies to our knowledge have taken into account interactions between milk yield and milk protein concentration. Harris and Pryce (2004) used the probability of the cow being inseminated in the first 3 wk of the breeding program and the probability of the cow calving to an AI (rather than to a later natural breeding by a herd bull) and showed that probabilities of these events for cows within the bottom $10 \%$ for milk protein concentration were 9 percentage points less than for cows in the highest $10 \%$ of milk protein concentrations ( 77 vs. $86 \%$; and 64 vs. $73 \%$, respectively). The same comparisons based on lowest and highest milk yields were not associated with significant effects on either measure of reproductive performance. Patton et al. (2007) intensively monitored 98 Holstein cows through 2 lactations. Cows were fed differing DMI and had various milking frequencies for the first 4 wk of lactation. They measured milk yield as well as milk protein concentration to identify energy-related factors that affect the interval from calving to first luteal activity, conception rate to first insemination, and the interval from calving to conception. None of milk yield during the first 4 wk of lactation, milk yield at insemination, or peak milk yield were significantly associated with reproductive performance. Higher milk protein concentration during the first $4 \mathrm{wk}$ of lactation was associated with significantly shorter intervals from calving to first luteal activity and higher probabilities of conception to first insemination, but not with the interval from calving to conception. Shorter intervals from calving to first luteal activity could be expected to increase the probability of insemination in the first 3 wk of the breeding period as reflected in Table 1. Having more cows cycle at least once before the estrus associated with an insemination will also increase conception rates to first service (Macmillan and Clayton, 1980). Effect estimates for these associations were not adjusted for milk yield. Madouasse et al. (2010) used milk recording data collected from 2,128 herds in England and Wales between 2004 and 2006 to obtain yield and composition variables measured at the first or second test day for use in predicting daily probability of conception. This probability decreased with higher milk weight and higher milk protein concentration on the second test day (each after accounting for the other). However, none of these studies assessed interactions between milk yield and milk protein concentration.

Based on our results, in populations such as the study population, increases in milk yield are associated with improved proportions of cows pregnant by wk 6 and 21 at low to moderate milk protein concentrations but with decreases in these reproductive measures at high milk protein concentrations. In contrast, for submission by wk 3 , neither adverse nor beneficial effects of milk yield were evident at high milk protein concentrations (Figure 1). Assuming these same effects for probabilities of submission among nonpregnant cows during the breeding period, the reductions in 6- and 21-wk pregnancy rates with increases in milk yield from 4,000 to $<5,000$ to $\geq 5,000 \mathrm{~kg}$ at high milk protein concentrations were due to lower conception rates. Among cows with high milk protein concentration $(\geq 3.75 \%)$, those with the highest milk yields $(\geq 5,000 \mathrm{~kg})$ had markedly lower crude (Table 3) and adjusted (Figure 2) conception rates to first service compared with those with milk yields of 4,000 to $<5,000 \mathrm{~kg}$ (18 vs. $37 \%$, respectively, but more modest differences in their crude $(75$ vs. $82 \%$; Table 1) and adjusted (Figure 1) submission rates by 3 wk. In contrast, with decreases in milk yield 
from 4,000 to $\leq 5,000$ to $<2,000 \mathrm{~kg}$ at high milk protein concentrations, the contributions from lower submission and conception rates in the reductions in 6- and 21-wk pregnancy rates were more similar. Among cows with high milk protein concentration $(\geq 3.75 \%)$, those with the lowest milk yields had lower crude (72 vs. $82 \%$ for 4,000 to $\leq 5,000 \mathrm{~kg}$; Table 1) and adjusted (Figure 1) submission rates by 3 wk and their adjusted conception rate to first service was also lower (Figure 2).

These relationships are likely to have genetic components. In New Zealand Friesians, milk, protein, and fat yields each had negative genetic correlations with pregnancy by wk 6 ; these ranged from -0.17 to -0.19 in first lactation and from -0.24 to -0.41 in second lactation (Grosshans et al., 1997). Also in New Zealand cows, Harris and Pryce (2004) calculated genetic correlations between milk yield and each of probability of the cow being inseminated in the first $21 \mathrm{~d}$ of the breeding program and the probability of the cow calving to an AI (rather than to a later natural breeding by a herd bull). Genetic correlations were -0.25 and -0.21 , respectively. In contrast, the genetic correlations with milk protein concentration were +0.18 and +0.20 , respectively. These genetic correlations may account for results from studies comparing strains of Holsteins derived from pasture-based or intensive feeding systems. Studies in New Zealand and Ireland have both shown that, whereas cows derived from the latter strains may have higher milk yields, they also had lower milk protein concentrations and lower reproductive performance (Harris and Kolver, 2001; Horan et al., 2005).

\section{CONCLUSIONS}

Even though early lactation milk protein concentration and milk yield are negatively associated, associations between milk protein concentration in early lactation and reproductive performance in Holstein cows were not due to confounding by milk yield. Associations between milk protein concentration and reproductive performance are weaker at higher early lactation milk yields. Mechanisms causing the associations between milk protein concentration and reproductive performance may be linked to milk yield, but these mechanisms operate over a wide range of milk yields $(<2,000$ to $\geq 5,000 \mathrm{~kg}$ in the first $120 \mathrm{~d}$ of lactation). Further research is required to identify the causes of these associations.

In the study population, increases in milk yield were associated with improved proportions of cows pregnant by wk 6 and 21 at low to moderate milk protein concentrations but with decreases in these reproductive measures at high milk protein concentrations. Thus, no simple relationship is present between milk yield and reproductive performance; effects of milk yield depend on milk protein concentration.

\section{ACKNOWLEDGMENTS}

We gratefully acknowledge the assistance of the veterinarians who supplied data for this study: Jakob Malmo (Maffra Veterinary Centre, Maffra, Victoria, Australia), Peter Younis and David Colson (The Vet Group, Timboon and Allansford, Victoria, Australia), Steve Jagoe (Warrnambool Veterinary Clinic, Warrnambool, Victoria, Australia), and Neil Leighton (Smithton Veterinary Services, Smithton, Tasmania, Australia), and the Australian Dairy Herd Improvement Scheme (ADHIS, Melbourne, Victoria, Australia) and Paul Koh in particular, who supplied data from the ADHIS database. This study was partly funded by the Department of Economic Development, Jobs, Transport and Resources, Government of Victoria, Victoria, Australia.

\section{REFERENCES}

ADHIS. 2015. Australian Dairy Herd Improvement Scheme. Accessed Oct. 15, 2015. http://www.adhis.com.au/.

Buckley, F., K. O'Sullivan, J. F. Mee, R. D. Evans, and P. Dillon. 2003. Relationships among milk yield, body condition, cow weight, and reproduction in spring-calved Holstein-Friesians. J. Dairy Sci. 86:2308-2319.

Eicker, S. W., Y. T. Grohn, and J. A. Hertl. 1996. The association between cumulative milk yield, days open, and days to first breeding in New York Holstein cows. J. Dairy Sci. 79:235-241.

Fahey, J., J. M. Morton, M. J. Auldist, and K. L. Macmillan. 2016. Associations between early lactation milk protein concentrations and the intervals to calving for Holstein cows of differing parity. Anim. Prod. Sci. http://dx.doi.org/http://dx.doi.org/10.1071/AN15777.

Fahey, J., J. M. Morton, and K. L. Macmillan. 2003. Relationship between milk protein percentage and reproductive performance in Australian dairy cows. Proc. N.Z. Soc. Anim. Prod. 63:82-86.

Fahey, J., J. M. Morton, and K. L. Macmillan. 2008. Associations between milk protein concentrations and preceding reproductive performance in Holstein-Friesian heifers and cows in Australia. Proc. N.Z. Soc. Anim. Prod. 68:69-72.

Grosshans, T., Z. Z. Xu, L. J. Burton, D. L. Johnson, and K. L. Macmillan. 1997. Performance and genetic parameters for fertility of seasonal dairy cows in New Zealand. Livest. Prod. Sci. 5:41-51.

Hamudikuwanda, H., H. N. Erb, and R. D. Smith. 1987. Effects of sixty-day milk yields on postpartum breeding performance in Holstein cows. J. Dairy Sci. 70:2355-2365.

Harris, B. L., and E. S. Kolver. 2001. Review of Holsteinization on intensive pastoral dairy farming in New Zealand. J. Dairy Sci. $76: \mathrm{E} 56-\mathrm{E} 61$.

Harris, B. L., and J. E. Pryce. 2004. Genetic and phenotypic relationships between milk protein percentage, reproductive performance and body condition score in New Zealand dairy cattle. Proc. N.Z. Soc. Anim. Prod. 64:127-131.

Horan, B., P. Dillon, P. Faverdin, L. Delaby, F. Buckley, and M. Rath. 2005. The influence of strain of Holstein-Friesian cows and pasture-based feed systems on milk yield, body weight, and body condition score. J. Dairy Sci. 88:1231-1243.

Kaufmann, W. 1976. Studies on the energy supply for high-yielding dairy cows and its importance for milk protein content and fertility. Kieler Milchwirtschaftliche Forschungsberichte 28:347-357. 
Kennedy, J., P. Dillon, K. O'Sullivan, F. Buckley, and M. Rath. 2003. Effect of genetic merit for milk production and concentrate feeding level on the reproductive performance of Holstein Friesian cows in a grass-based system. Anim. Sci. 76:297-308.

Kinsel, M. L., W. E. Marsh, P. L. Ruegg, and W. G. Etherington. 1998. Risk factors for twinning in dairy cows. J. Dairy Sci. 81:989-993.

Klaas, I. C., U. Wessels, H. Rothfuss, B.-A. Tenhagen, W. Heuwieser, and E. Schallenberger. 2004. Factors affecting reproductive performance in German Holstein-Friesian cows with a special focus on postpartum mastitis. Livest. Prod. Sci. 86:233-238.

Laben, R. L., R. Shanks, P. J. Berger, and A. E. Freeman. 1982. Factors affecting milk yield and reproductive performance. J. Dairy Sci. 65:1004-1015.

Lampo, P., F. Vanschoubroek, and A. Willems. 1963. De invloed van de kalvingsmaand, de melkproduktie, het vet-, eiwet- en het laktosegehalte op de duur van de tussendrachtperiode bij oostvlaamse stamboekvaarzen. Vlaams Diergeneeskundig Tijdschrift 32:217231. (Abstract only).

Leaver, J. D. 1983. Effect of condition score and milk protein content at service on conception rates. Pages 36-37 in Annual Report, Crichton Royal Farm. West of Scotland Agricultural College, Dumfries.

Macmillan, K. L., and D. G. Clayton. 1980. Factors influencing the interval to post-partum-oestrus, conception date and empty rate in an intensively managed dairy herd. Proc. NZ Soc. Anim. Prod. 40:236-239.

Madouasse, A., J. N. Huxley, W. J. Browne, A. J. Bradley, I. L. Dryden, and M. J. Green. 2010. Use of individual cow milk recording data at the start of lactation to predict the calving to conception interval. J. Dairy Sci. 93:4677-4690.

McDougall, S. 2003. Resynchrony of previously anoestrous cows and treatment of cows not detected in oestrus that had a palpable corpus luteum with prostaglandin f2alpha. N. Z. Vet. J. 51:117-124.

McGowan, M. R., R. F. Veerkamp, and L. Anderson. 1996. Effects of genotype and feeding system on the reproductive performance of dairy cattle. Livest. Prod. Sci. 46:33-40.

Miettinen, P. V. A., and J. J. Setala. 1993. Relationships between subclinical ketosis, milk production and fertility in Finnish dairy cattle. Prev. Vet. Med. 17:1-8.
Morton, J. 2011. InCalf Fertility Data Project 2011, Dairy Australia, Southbank, Melbourne, Australia.

Morton, J. M. 2004. Determinants of reproductive performance of dairy cows in commercial herds in Australia. $\mathrm{PhD}$ thesis, Faculty of Veterinary Science, University of Melbourne, Melbourne, Australia. Accessed Oct. 15, 2015. http://hdl.handle.net/11343/38864.

Morton, J. M., M. J. Auldist, M. L. Douglas, and K. L. Macmillan. 2016. Associations between milk protein concentration at various stages of lactation and reproductive performance in dairy cows. J. Dairy Sci. 99:10044-10056. http://dx.doi.org/10.3168/jds.201611276 .

Moss, N., I. J. Lean, S. W. J. Reid, and D. R. Hodgson. 2002. Risk factors for repeat-breeder syndrome in New South Wales dairy cows. Prev. Vet. Med. 54:91-103.

Patton, J., D. A. Kenny, S. McNamara, J. F. Mee, F. P. O'Mara, M. G. Diskin, and J. J. Murphy. 2007. Relationships among milk production, energy balance, plasma analytes, and reproduction in Holstein-Friesian cows. J. Dairy Sci. 90:649-658.

Pinto, A., P. Bouca, A. Chevallier, S. Freret, B. Grimard, and P. Humblot. 2000. Sources of variation of fertility and of embryonic mortality rates in the dairy cow. J. Reprod. Fertil. 26:32. (Abstr.)

Shanks, R. D., P. J. Berger, A. E. Freeman, and F. N. Dickinson. 1982. Genetic and phenotypic relations of milk production and postpartum length with health and lactation curve traits by lactation. J. Dairy Sci. 65:1612-1623.

Silke, V., M. G. Diskin, D. A. Kenny, M. P. Boland, P. Dillon, J. F. Mee, and J. M. Sreenan. 2002. Extent, pattern and factors associated with late embryonic loss in dairy cows. Anim. Reprod. Sci. $71: 1-12$.

Xu, Z. Z., and L. Burton. 2003. Reproductive performance of dairy cows in New Zealand. Final Report of the Fertility Monitoring Project. Livestock Improvement, Hamilton, New Zealand. Accessed Oct. 15， 2015. http://www.lic.co.nz/user/file/Monitoring\%20 fertility\%20report\%20for\%20distribution.pdf. 